\title{
GENE-BASED MARKERS IN MARKER-ASSISTED SELECTION TO SCREEN TOMATO GENOTYPES RESISTANT TO FUSARIUM WILT, LATE BLIGHT, VERTICILLIUM WILT, LEAF MOLD, BACTERIAL SPOT AND BACTERIAL SPECK
}

\author{
Heba A. Mahfouze, Sherin A. Mahfouze
}

Genetics and Cytology Department, Genetic Engineering and Biotechnology Research Division, National Research Centre, Dokki, 12622, Egypt.

\section{ART I CLE IN F O}

\section{Article history}

Received: June 14, 2021

Revised: August 05, 2021

Accepted: August 08, 2021

Keywords

Allele-specific markers

SCAR

SNP

InDel

CAPS

\section{A B S T R A C T}

Corresponding Author: Sherin A. Mahfouze

Email: sherinmahfouze@yahoo.com

(c) The Author(s) 2021.

\section{INTRODUCTION}

Breeding for biotic stress resistance in the plants is considered one of the most crucial ways in the breeding programs. However, selecting the germplasm resistant or tolerant to a specific pathogen is more difficult (Peries, 1971). Furthermore, the use of molecular markers in the identification and characterization of resistance genes has become an important tool, because they are not affected by environmental conditions. Besides, molecular markers supply a unique chance to select a big number of germplasms in a short time. Up to date, a big number of gene-based markers have been identified in various crops, including tomato (Foolad, 2007).
Tomato (Solanum lycopersicum L.), one of the most important horticultural crops of Egypt and worldwide. It is infected with many fungal and bacterial diseases e.g., wilt disease caused by Fusarium oxysporum f. sp. lycopersici, verticillium wilt (Verticillium dahliae and $V$. alboatrum), late blight (Phytophthora infestans), leaf mold (Cladosporium fulvum), bacterial spot (Xanthomonas campestris pv. vesicatoria) and bacterial speck (Pseudomonas syringae pv. tomato) are a dangerous threat to tomato farming (Lee et al., 2015). There are a big number of tomato germplasms, many resistance loci for various diseases have been reported (van Ooijen et al., 2007). Hence, molecular markers become an important tool in the tomato breeding 
programs for the detection of resistance genes of the above-mentioned diseases (Arens et al., 2009; Shi and Vierling, 2011).

Fusarium wilt disease in tomato is caused by fungus $F$. oxysporum f. sp. lycopersici (Fol). Three races of Fusarium fungus were known (1, 2, and 3) (Grattidge, 1982). Resistance to Fol has been reported in multiple wild tomato species. The resistance genes $I-1, I-2$ and $I-3$ have been indicated in the wild tomato $S$. pimpinellifolium accession "PI79532", S. lycopersicum $\times$ S. pimpinellifolium hybrid "PI126915" and S. pennellii "LA716" respectively, which give resistance to Fol race 1, 2, and 3, respectively (Bohn and Tucker, 1939; Simons et al., 1998; Scott and Jones, 1989b). Besides, the single dominant gene (I-7) has been recorded in $S$. pennellii "PI414773" that confers resistance to Fol races 1, 2, and 3 (Gonzalez-Cendales et al., 2015).

Vascular wilt or verticillium wilt disease in tomato is a soil-born fungal pathogen caused by Verticillium dahliae and $V$. alboatrum (Fradin and Thomma, 2006). The resistance gene ( $\mathrm{Ve}$ ) is located on chromosome 9 ( $\mathrm{chr} 9$ ), which confers resistance to $V$. alboatrum race 1 (Diwan et al., 1999).

Late blight (LB) disease of tomato is caused by fungus Phytophthora infestans (Rodewald and Trognitz, 2013); a few main resistance genes to LB in tomato have been reported. Three resistance loci to LB, $P h 1, P h 2$ and $P h 3$ from wild tomato $S$. pimpinellifolium have been located on chr 7, chr 10 and chr 9, respectively. The latter refers to incomplete resistance to $P$. infestans races (Foolad et al., 2008; Kim and Mutschler, 2006; Zhang et al., 2013). Furthermore, the resistance gene (Ph4) in accession $S$. habrochaites LA1033 on chr 2 has been identified (Kole et al., 2006), and Ph5-1 and Ph5-2, which have been found in S. pimpinellifolium "PSLP153", are mapped at chr 1 and chr 10, respectively (Merk et al., 2012; Merk and Foolad, 2011).

Tomato leaf mold, which is caused by the fungus Cladosporium fulvum, causes significant yield loss in glasshouse-grown tomatoes (Rivas and Thomas, 2005). Multiple resistance genes ( $C f$ ) to leaf mold have been recognized in wild tomato types namely, $C f-2, C f-4, C f-4 E$, Cf-5 and Cf-9 (Dixon et al., 1996; Dixon et al., 1998; Takken et al., 1999). Both $C f-4$ and $C f-9$ originated from $S$. habrochaites and S. pimpinellifolium, respectively. They are mapped at the same locus on chr 1 (Parniske et al., 1997). Cf-2 and Cf-5 indicated in S. pimpinellifolium and $L$. esculentum var. cerasiforme, respectively. Both $C f$ -
2 and $C f-5$ are mapped at chr 6 (Dixon et al., 1998).

Bacterial spot disease in tomato, which is caused by a gram-negative bacterium Xanthomonas campestris pv. vesicatoria $(\mathrm{Xcv})$, is a constant threat to the tomato grown in both the greenhouse and the field (Jones et al., 1998). Five races of $X c v$ (T1 to T5) are identified by various tomato germplasms. Resistance genes, involving $X v 3$ and $X v 4$, are responsible for mechanisms of hypersensitivity reaction (HR) resistance. Xv3 discovered in $S$. lycopersicum "H7981" and $S$. pimpinellifolium (accessions "PI126932" and "PI128216") confers resistance against T3 races (Wang et al., 2011). Besides, resistance locus $R x-4$ located on chr 11 (accession "PI128216") also refers to resistance against T3 races (Robbins et al., 2009). A dominant resistance locus $\mathrm{Xv} 4$ on chr 3 has been found in $S$. pennellii LA716, which confers resistance to T4 strains (Astua-Monge et al., 2000). Both $R x-1$ and $R x-2$ are mapped at chr 1 , while $R x-3$ is located on chr 5 , has been recognized in $S$. lycopersicum (accession "H7998"), which gives HR resistance to T1 strains (Scott and Jones, 1989a).

Bacterial speck disease in tomato is caused by a gramnegative bacterium Pseudomonas syringae pv. tomato. The single dominant gene, Pto has been located on chr 5 , which confers resistance to the bacterial speck in $S$. pimpinellifolium (Salmeron et al., 1996; Jia et al., 1997). The other genes originated from wild tomato $S$. habrochites "LA1777" are included in resistance against bacterial speck e.g., bsRr1-1, bsRr1-2 and bsRr1-12 are located on chr 1, chr 2 and chr 12, respectively (Thapa et al., 2015).

The purpose of this study was to identify the resistance alleles corresponding to fusarium wilt, verticillium wilt, late blight, leaf mold, bacterial spot, and bacterial speck of 19 tomato genotypes by molecular markers, which will be used as marker-assisted selection (MAS) in tomato breeding programs.

\section{MATERIALS AND METHODS}

\section{Plant materials}

A total of 19 tomato genotypes, including accessions and commercial cultivars, were used in this study. The name and source of these genotypes were mentioned in Table (1). Ten tomato seeds from each of the genotype were sown in a greenhouse at $27{ }^{\circ} \mathrm{C}: 16{ }^{\circ} \mathrm{C}$ (Light:Dark), a photoperiod of L16:D8 $\mathrm{h}$ and relative humidity of 68- 
$75 \%$. Seedlings were planted in peat moss: sand $(2: 1)$ in pots (Mahfouze and Mahfouze, 2019).

\section{Isolation of DNA}

DNA was isolated from fresh tomato leaves for each genotype. $30 \mathrm{mg}$ of tissue was ground in liquid nitrogen and extracted with the DNA purification Kit (Bio Basic, Inc., Markham, Canada) following the manufacturer's instructions. DNA quality and quantity were determined by agarose gel electrophoresis and Spectrophotometer. DNA concentrations were adjusted to $50 \mathrm{ng} / \mu \mathrm{l}$ and extracts were frozen at $-20^{\circ} \mathrm{C}$.

Table 1. Tomato genotypes used in this study.

\begin{tabular}{clcclc}
\hline No. & Genotype & Source & No. & Genotype & Source \\
\hline 1 & Solanum hirsutum 24036 & CGN $^{*}$ & 11 & S. chilense 56139 & CGN $^{*}$ \\
2 & S. galapagense 0317 & TGRC $^{* *}$ & 12 & S. lycopersicon cv. Super Marmande & Egypt $^{* * *}$ \\
3 & S. neoricki 0247 & TGRC & 13 & S. lycopersicon cv. Strain B F1 & Egypt \\
4 & S. arcanum 1346 & TGRC & 14 & S. corneliomulleri 1283 & TGRC \\
5 & S. corneliomulleri 1274 & TGRC & 15 & S. habrochaites 1739 & TGRC \\
6 & S. pennellii 1733 & TGRC & 16 & S. pimpinellifolium 1279 & TGRC \\
7 & S. huaylasense 1358 & TGRC & 17 & S. pimpinellifolium 1332 & TGRC \\
8 & S. pimpinellifolium 1342 & TGRC & 18 & S. pennellii 2963 & TGRC \\
9 & S. peruvianum 1333 & TGRC & 19 & S. pennellii 1942 & TGRC \\
10 & S. habrochaites 1352 & TGRC & & & \\
\hline
\end{tabular}

$\mathrm{CGN}^{*}=$ Centre for Genetic Resources, Netherlands (http://www.wur.nl).

$\mathrm{TGRC}^{* *}=$ Tomato Genetics Resource Center (TGRC), Department of Plant Sciences, University of California, Davis, CA 95616 (http://tgrc.ucdavis.edu).

${ }^{* * *}$ Two commercial cultivars were purchased from Egyptian Company for Seeds, Oils and Chemicals, Egypt.

\section{PCR amplification of resistance alleles}

PCR with a gene-based marker was performed in $25 \mu \mathrm{l}$ reactions containing $2.5 \mu \mathrm{l}$ of $2.5 \mathrm{mM}$ dNTPs, $5 \mu \mathrm{l}$ of $5 \mathrm{X}$ buffer, $2.5 \mu \mathrm{l}$ of $2.5 \mathrm{mM} \mathrm{MgCl} 2,0.1 \mu \mathrm{l}$ (0.5 units) Taq DNA polymerase (Promega Corp., Madison, WI), $2.5 \mu \mathrm{l}$ each forward and reverse primer at $10 \mu \mathrm{M}, 1 \mu \mathrm{l}$ of DNA extract and $8.9 \mu \mathrm{ldd} \mathrm{H}_{2} \mathrm{O}$. PCR cycles were $94^{\circ} \mathrm{C}$ for $4 \mathrm{~min}, 35$ cycles of $94{ }^{\circ} \mathrm{C}$ for $30 \mathrm{sec}$, annealing temperature (Table 2) for 1 min and $72{ }^{\circ} \mathrm{C}$ for $1.5 \mathrm{~min}$. These cycles were followed by $72{ }^{\circ} \mathrm{C}$ for $10 \mathrm{~min}$ and then the reaction was held at $4{ }^{\circ} \mathrm{C}$. PCR reactions were performed in the Thermocycler (Biometra, biomedizinische Analytik GmbH). For CAPS markers, PCR products were digested by the restriction enzyme RsaI (Table 2). $25 \mu \mathrm{l}$ reaction mixture containing $10.75 \mu \mathrm{l}$ $\mathrm{ddH}_{2} \mathrm{O}, 3 \mu \mathrm{l}$ buffer, $0.25 \mu \mathrm{l}$ BSA (Bovine serum albumin), 1 $\mu \mathrm{l}$ restriction enzyme (RsaI) $10 \mathrm{U} / \mu \mathrm{l}$ (Promega Corp.) and $10 \mu \mathrm{l}$ PCR reaction mixture. The reaction mixture was placed in a $65^{\circ} \mathrm{C}$ water bath for about $2 \mathrm{~h}$ according to the manufacturer's instructions.

\section{Gel electrophoresis}

All the PCR and restriction-digested products were separated on a $1 \%$ agarose gel electrophoresis in $1 \mathrm{X}$ TBE buffer, stained with RedSafe Nucleic Acid Staining
Solution $(1 / 20,000)$ (iNtRON Biotechnology, Inc. Kr) and were visualized with UV light. The size of each band was determined with reference to a size marker of $100 \mathrm{bp}$ DNA ladder (BioRoN, Germany).

\section{RESULTS}

\section{Fungi-high-efficiency markers for marker-assisted selection (MAS) in tomato}

Five molecular markers linked with three fungal diseases were estimated to select tomato genotypes carrying resistance alleles for MAS programs. For Fusarium wilt, two markers SCAR I1 and SCAR I1 86.1 were applied to the target $I-1$ gene. However, the SNP marker is associated with $V e$ gene, which gives resistance to verticillium wilt. Besides, the SCAR Ph3 marker linked to $P h 3$ responsible for resistance to late blight. Finally, the InDel2_Cf-9/Cf-4 marker was used to detect resistance allele to leaf mold $(C f)$ disease.

\section{Gene-based SCAR markers for I-1 resistance}

Two SCAR markers (SCAR I1 and SCAR I1 86.1) (Table 2) were used to detect resistant and susceptible tomato genotypes to fusarium wilt disease. 
Table 2. Sequence of primers used in this study.

\begin{tabular}{|c|c|c|c|c|c|c|c|c|c|}
\hline $\begin{array}{l}\text { Primer } \\
\text { name }\end{array}$ & $\begin{array}{c}\text { Marker } \\
\text { name }^{\mathrm{a}}\end{array}$ & $\begin{array}{l}\text { Disease } \\
\text { name }\end{array}$ & $\begin{array}{c}R- \\
\text { gene }^{\mathrm{b}}\end{array}$ & $\begin{array}{c}\text { Chromosome } \\
\text { No } \\
\end{array}$ & Single nucleotide sequence $\left(5^{\prime}-3^{\prime}\right)$ & $\begin{array}{l}\text { Annealing } \\
\text { temp. }{ }^{\circ} \mathrm{C}\end{array}$ & $\begin{array}{l}\text { Restr. } \\
\text { enzyme }\end{array}$ & $\begin{array}{l}\text { Molecular size } \\
\text { of PCR (bp) }\end{array}$ & References \\
\hline $\begin{array}{l}\text { SCAR I1F } \\
\text { SCAR I1R }\end{array}$ & SCAR & $\begin{array}{l}\text { Fusarium } \\
\text { wilt }\end{array}$ & $I-1$ & 11 & $\begin{array}{l}\text { CGAATCTGTATATTACATCCGTCGT } \\
\text { GGTGAATACCGATCATAGTCGAG }\end{array}$ & 55 & - & $\begin{array}{l}\mathrm{R}=130 \\
\text { Other }=92\end{array}$ & $\begin{array}{l}\text { Scott et al. } \\
(2004)\end{array}$ \\
\hline $\begin{array}{l}\text { SCAR I1 } \\
86.1 \mathrm{~F} \\
\text { SCAR I1 } \\
86.1 \mathrm{R}\end{array}$ & SCAR & $\begin{array}{l}\text { Fusarium } \\
\text { wilt }\end{array}$ & $I-1$ & 11 & $\begin{array}{l}\text { TGTTGGCGGTAGTGATGAGA } \\
\text { TCACCAATATTAGGCCCCTTT }\end{array}$ & 52 & - & $\begin{array}{l}\mathrm{R}=314, \mathrm{~S}= \\
583 \\
\mathrm{H}=314 \text { and } \\
583\end{array}$ & $\begin{array}{c}\text { Gonzalez- } \\
\text { Cendales et al. } \\
\text { (2014) }\end{array}$ \\
\hline $\begin{array}{l}\text { Ve SNP F } \\
\text { Ve SNP R }\end{array}$ & SNP & $\begin{array}{l}\text { Verticillium } \\
\text { wilt }\end{array}$ & Ve & 9 & $\begin{array}{l}\text { CCTTGATGGGGTTGATCTTTCGT } \\
\text { GTAGGTGAGTTTCTTGGACAGTCGA }\end{array}$ & 57 & - & $\begin{array}{l}\mathrm{R}=476, \mathrm{~S}=158 \\
\text { Other }=580\end{array}$ & $\begin{array}{l}\text { Kawchuk et al. } \\
\qquad \text { (2001) }\end{array}$ \\
\hline $\begin{array}{l}\text { SCAR Ph3 F } \\
\text { SCAR Ph3 R }\end{array}$ & SCAR & Late blight & Ph3 & 9 & $\begin{array}{l}\text { CTACTCGTGCAAGAAGGTAC } \\
\text { TCCACATCACCTGCCAGTTG }\end{array}$ & 50 & - & $S=154, R=176$ & $\begin{array}{l}\text { Jung et al. } \\
2015\end{array}$ \\
\hline $\begin{array}{l}\text { InDel2_Cf- } \\
\text { 9/Cf-4 F } \\
\text { InDel2_Cf- } \\
\text { 9/Cf-4 R }\end{array}$ & InDel & Leaf mold & $\begin{array}{c}C f- \\
9 / C f-4\end{array}$ & 1 & $\begin{array}{l}\text { TCCTAAACCTCTATGGAATCTCAC } \\
\text { GGAGTGAATTCGGAATACGACC }\end{array}$ & 55 & - & $\begin{array}{l}\mathrm{R}=434(C f-9 c) \\
\mathrm{R}=297(C f-4)\end{array}$ & $\begin{array}{l}\text { Kim et al. } \\
\text { (2017) }\end{array}$ \\
\hline $\begin{array}{l}\text { pcc12 Indel } \\
\text { Rx4 F } \\
\text { pcc12 Indel } \\
\text { Rx4 R }\end{array}$ & InDel & $\begin{array}{l}\text { Bacterial } \\
\text { spot }\end{array}$ & $R \times 4$ & 11 & $\begin{array}{l}\text { TCCACATCAAATGCGTTTCT } \\
\text { TTCCAATCCTTTCCATTTCG }\end{array}$ & 52 & - & $\begin{array}{l}R=113 \\
S=119\end{array}$ & $\begin{array}{l}\text { Pei et al. } \\
(2012)\end{array}$ \\
\hline $\begin{array}{l}\text { Pto CAPSf } \\
\text { Pto CAPS R }\end{array}$ & CAPS & $\begin{array}{l}\text { Bacterial } \\
\text { speck }\end{array}$ & Pto & 5 & $\begin{array}{l}\text { ATCTACCCACAATGAGCATGAGCTG } \\
\text { GTGCATACTCCAGTTTCCAC }\end{array}$ & 60 & RsaI & $\begin{array}{l}\mathrm{R}=552 \\
\mathrm{~S}=113 \text { and } \\
439\end{array}$ & $\begin{array}{l}\text { Coaker and } \\
\text { Francis, } \\
(2004)\end{array}$ \\
\hline
\end{tabular}

aSCAR= Sequence characterized amplified region, SNP=Single nucleotide polymorphism, InDel= PCR based Insertion-deletions, CAPS=Cleaved amplified polymorphic sequences.

besistance genes of disease.

${ }^{c} C f-9$ and its paralogs.

The primer set SCAR I1 scored two bands of (130 and $92 \mathrm{bp}$ ) in all tested tomato genotypes, which refer to the presence of resistance allele I-1 (Figure 1 and Table 3). This result indicated that the primer SCAR I1 has not differentiated between the resistant and susceptible tomato lines to $F$. oxysporum f. sp. Lycopersici. Consequently, this primer SCAR I1 cannot be 74 applied in the tomato breeding programs for the selection of resistance allele $I-1$ to fusarium wilt fungus.

For SCAR I1 86.1, it scored one amplicon of $314 \mathrm{bp}$ in two tomato accessions containing homozygous dominant allele $I-1$ e.g., $S$. pimpinellifolium 1279 and 1332. Furthermore, SCAR I1 86.1 recorded one amplified fragment with a molecular size of $583 \mathrm{bp}$ in four tomato germplasms may be susceptible to fusarium wilt disease such as $S$. galapagense 0317, S. pimpinellifolium 1342, S. lycopersicon cv. Super Marmande and $S$. lycopersicon cv. Strain B F1, which have a recessive allele with homozygous (Figure 2 and Table 3). 
Table 3. Tomato genotypes used to evaluate gene-based markers for resistances against tomato pathogens.

\begin{tabular}{|c|c|c|c|c|c|c|c|c|}
\hline \multirow{3}{*}{ No. } & \multirow{3}{*}{ Genotype } & \multicolumn{7}{|c|}{ Resistance genes and DNA markers } \\
\hline & & \multicolumn{2}{|c|}{ Fusarium wilt $(I-1)$} & \multirow{2}{*}{$\begin{array}{r}\begin{array}{l}\text { Verticillium } \\
\text { wilt }(\mathrm{Ve})\end{array} \\
\text { Ve SNPb }\end{array}$} & \multirow{2}{*}{$\begin{array}{l}\begin{array}{l}\text { Late blight } \\
(P h 3)\end{array} \\
\text { SCAR Ph3 }\end{array}$} & \multirow{2}{*}{$\begin{array}{l}\text { Leaf mold (Cf- } \\
\text { 9/Cf-4) } \\
\begin{array}{l}\text { InDel2_Cf-9/Cf- } \\
4^{c}\end{array}\end{array}$} & \multirow{2}{*}{$\begin{array}{l}\text { Bacterial spot } \\
(R x 4)\end{array}$} & \multirow{2}{*}{$\begin{array}{c}\text { Bacterial speck } \\
(\text { Pto })\end{array}$} \\
\hline & & SCAR $^{\mathrm{a}} \mathrm{I} 1$ & $\begin{array}{c}\text { SCAR I1 } \\
86.1\end{array}$ & & & & & \\
\hline 1 & Solanum hirsutum 24036 & $\mathrm{RR}^{\mathrm{e}}$ & - & - & RR & $\operatorname{RR}(C f-9)$ & - & - \\
\hline 2 & S. galapagense 0317 & $\mathrm{RR}$ & $\mathrm{rr}^{\mathrm{f}}$ & - & $\mathrm{RR}$ & $\mathrm{RR}(C f-g)$ & - & - \\
\hline 3 & S. neoricki 0247 & $\mathrm{RR}$ & - & - & $\operatorname{Rrg}^{\mathrm{g}}$ & $\mathrm{RR}(C f-9 / C f-4)$ & $\mathrm{rr}$ & $\mathrm{Rr}$ \\
\hline 4 & S. arcanum 1346 & $\mathrm{RR}$ & - & - & $\mathrm{Rr}$ & $\mathrm{RR}(C f-9 / C f-4)$ & $\mathrm{rr}$ & $\mathrm{RR}$ \\
\hline 5 & S. corneliomulleri 1274 & $\mathrm{RR}$ & - & $\mathrm{rr}$ & - & $\mathrm{RR}(C f-9 / C f-4)$ & $\mathrm{rr}$ & $\mathrm{RR}$ \\
\hline 6 & S. pennellii 1733 & $\mathrm{RR}$ & - & - & RR & $\mathrm{RR}(C f-g)$ & $\mathrm{rr}$ & $\mathrm{RR}$ \\
\hline 7 & S. huaylasense 1358 & $\mathrm{RR}$ & - & - & - & $\mathrm{RR}(C f-9 / C f-4)$ & $\mathrm{rr}$ & $\mathrm{RR}$ \\
\hline 8 & S. pimpinellifolium 1342 & $\mathrm{RR}$ & $\mathrm{rr}$ & - & $\mathrm{RR}$ & $\mathrm{RR}(C f-9)$ & $\mathrm{rr}$ & $\mathrm{RR}$ \\
\hline 9 & S. peruvianum 1333 & $\mathrm{RR}$ & - & - & $\mathrm{RR}$ & $\mathrm{RR}(C f-9 / C f-4)$ & $\mathrm{rr}$ & $\mathrm{RR}$ \\
\hline 10 & S. habrochaites 1352 & RR & - & - & - & $\mathrm{RR}(C f-9)$ & $\mathrm{rr}$ & $\mathrm{RR}$ \\
\hline 11 & S. chilense 56139 & $\mathrm{RR}$ & - & - & $\mathrm{RR}$ & $\mathrm{RR}(C f-9)$ & $\mathrm{rr}$ & $\mathrm{RR}$ \\
\hline 12 & $\begin{array}{l}\text { S. lycopersicon cv. Super } \\
\text { Marmande }\end{array}$ & RR & $\mathrm{rr}$ & - & - & $\mathrm{RR}(C f-g)$ & $\mathrm{rr}$ & $\mathrm{Rr}$ \\
\hline 13 & $\begin{array}{l}\text { S. lycopersicon cv. Strain } \\
\text { B F1 }\end{array}$ & $\mathrm{RR}$ & $\mathrm{rr}$ & - & - & $\mathrm{RR}(C f-9 / C f-4)$ & $\mathrm{rr}$ & $\mathrm{Rr}$ \\
\hline 14 & S. corneliomulleri 1283 & $\mathrm{RR}$ & - & rr & - & $\mathrm{RR}(C f-9 / C f-4)$ & $\mathrm{rr}$ & $\mathrm{RR}$ \\
\hline 15 & S. habrochaites 1739 & $\mathrm{RR}$ & - & - & - & - & $\mathrm{rr}$ & $\mathrm{RR}$ \\
\hline 16 & S. pimpinellifolium 1279 & $\mathrm{RR}$ & $\mathrm{RR}$ & $\mathrm{rr}$ & - & $\mathrm{RR}(C f-g)$ & $\mathrm{rr}$ & $\mathrm{RR}$ \\
\hline 17 & S. pimpinellifolium 1332 & $\mathrm{RR}$ & $\mathrm{RR}$ & - & - & $\mathrm{RR}(C f-g)$ & $\mathrm{rr}$ & $\mathrm{RR}$ \\
\hline 18 & S. pennellii 2963 & $\mathrm{RR}$ & - & - & - & $\mathrm{RR}(C f-g)$ & $\mathrm{rr}$ & $\mathrm{RR}$ \\
\hline 19 & S.pennellii 1942 & RR & - & $\mathrm{rr}$ & - & $\operatorname{RR}(C f-9 / C f-4)$ & $\mathrm{rr}$ & $\mathrm{RR}$ \\
\hline
\end{tabular}

$\mathrm{SCAR}^{\mathrm{a}}=$ Sequence characterized amplified region, $\mathrm{SNP}^{\mathrm{b}}=$ Single nucleotide polymorphism, InDel $^{\mathrm{c}}=$ PCR based Insertion-deletions and CAPS ${ }^{\mathrm{d}}=$ Cleaved amplified polymorphic sequence.

$\mathrm{RR}^{\mathrm{e}}=$ Resistance allele, homozygote, $\mathrm{rr}^{\mathrm{f}}=$ Susceptibility allele, homozygote, $\mathrm{Rr}^{\mathrm{g}}=$ Heterozygote, - = Absence of allele. 


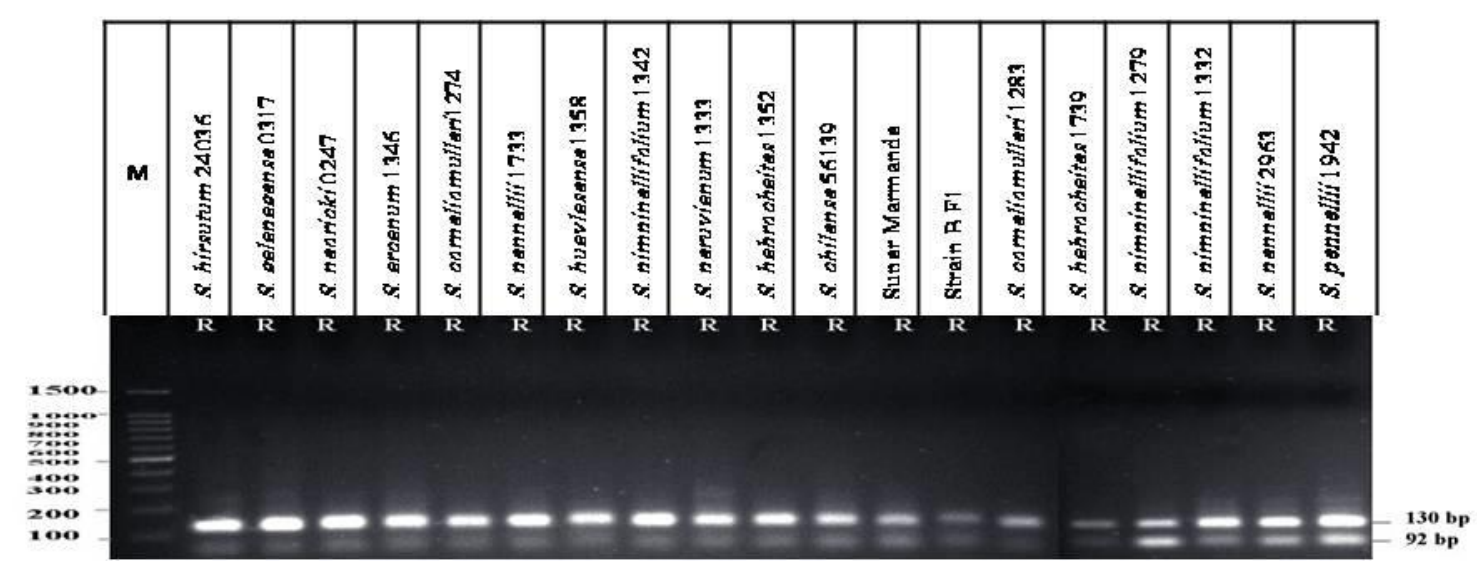

Figure 1. PCR fragments represent primer pair SCAR I1 amplified from 19 tomato genotypes, resolved in $1 \%$ agarose gel. Lane $\mathrm{M}=100 \mathrm{bp}$ DNA ladder; $\mathrm{R}=$ homozygous resistant genotypes.

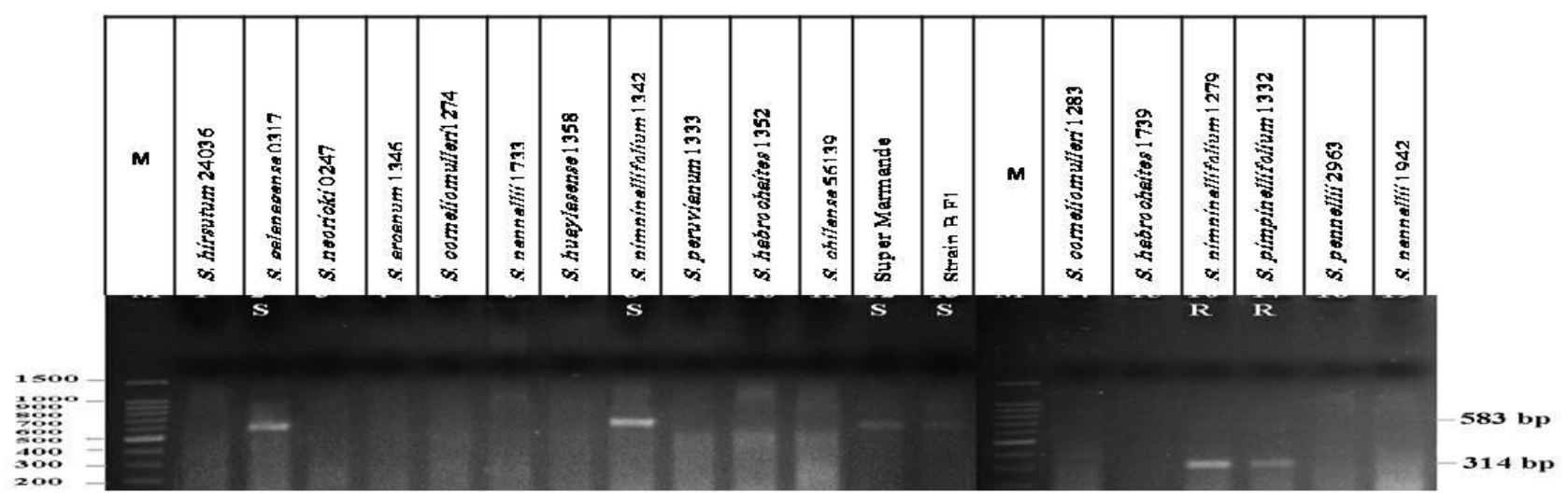

Figure 2. PCR fragments represent primer set SCAR I1 86.1 amplified from 19 tomato genotypes, resolved in 1\% agarose gel. Lane M: 100 bp DNA ladder; $\mathrm{R}=$ homozygous resistant genotypes; $\mathrm{S}=$ susceptible genotypes.

The primer set SCAR I1 scored two bands of $(130$ and 92 bp) in all tested tomato genotypes, which refer to the presence of resistance allele $I-1$ (Figure 1 and Table 3). This result indicated that the primer SCAR I1 has not differentiated between the resistant and susceptible tomato lines to $F$. oxysporum f. sp. Lycopersici. Consequently, this primer SCAR I1 cannot be applied in the tomato breeding programs for the selection of resistance allele $I-1$ to fusarium wilt fungus.

For SCAR I1 86.1, it scored one amplicon of $314 \mathrm{bp}$ in two tomato accessions containing homozygous dominant allele I-1 e.g., S. pimpinellifolium 1279 and 1332. Furthermore, SCAR I1 86.1 recorded one amplified fragment with a molecular size of $583 \mathrm{bp}$ in four tomato germplasms may be susceptible to fusarium wilt disease such as S. galapagense 0317, S. pimpinellifolium 1342, S. lycopersicon cv. Super Marmande and S. lycopersicon cv. Strain B F1, which have a recessive allele with homozygous (Figure 2 and Table 3).

\section{Gene-based SNP marker for Ve1 resistance}

PCR amplification of DNA from 19 tested tomato accessions using primer set Ve SNP, gave a faint band of $158 \mathrm{bp}$ in the four tomato genotypes expected to be susceptible to fungus verticillium wilt i.e., $S$. corneliomulleri 1274 and 1283, S. pimpinellifolium 1279 and S. pennellii 1942 (Figure 3 and Table 3). Moreover, the other 15 tomato genotypes have not shown any unique bands. Our results have not recorded any tomato genotypes resistant to verticillium wilt disease.

\section{Gene-based SCAR marker for $\boldsymbol{P h} 3$ resistance}

A PCR assay was used by a single pair of primer SCAR $\mathrm{Ph} 3$ to amplify the resistance gene to late blight (Ph3). Among the 19 studied tomato genotypes, six lines were homozygous for the $P h 3$ allele, which gave a unique band 
of 176 bp like S. hirsutum 24036, S. galapagense 0317, S. pennellii $1733, S$. pimpinellifolium 1342 , peruvianum 1333 and S. chilense 56139 (Figure 4 and Table 3). Three genotypes were heterozygous that scored two amplicons with molecular sizes of 154 and 176 bp e.g., S. neoricki
0247 and S. arcanum 1346 are expected to be $P h 3$ resistant. In addition, the other tomato lines have not scored any products. On the other hand, none of the studied tomato lines were homozygous recessive for the ph3 allele (Figure 4 and Table 3).

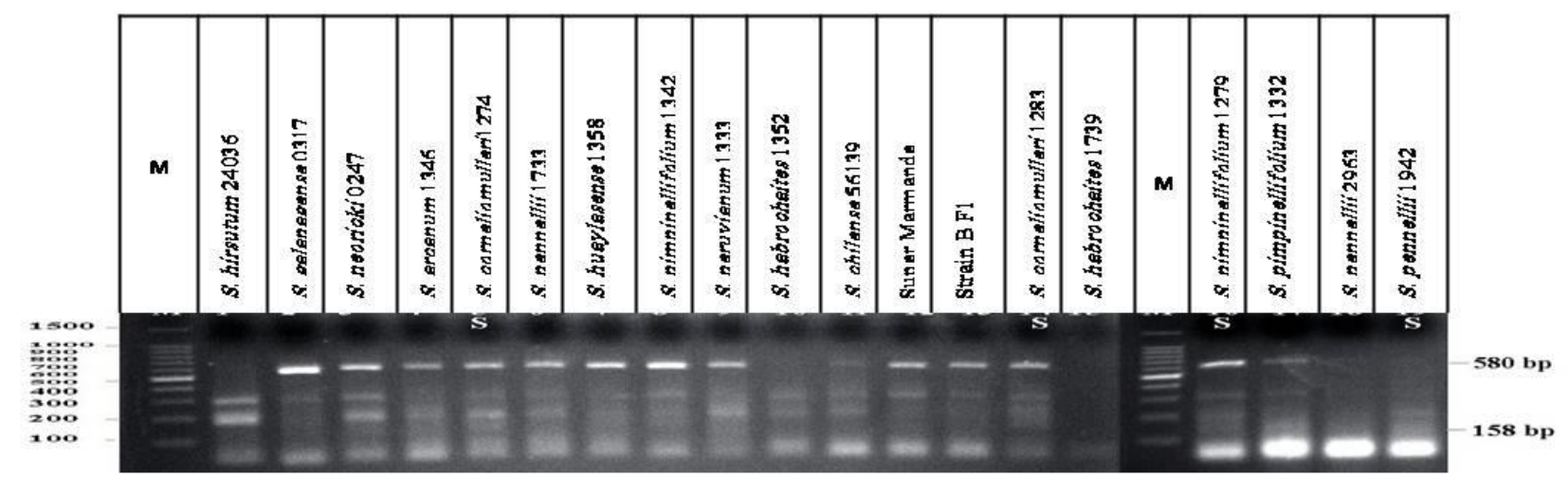

Figure 3. PCR fragments represent primer pair Ve SNP amplified from 19 tomato genotypes, resolved in $1 \%$ agarose gel. Lane M: 100 bp DNA ladder; $\mathrm{S}=$ susceptible genotypes.

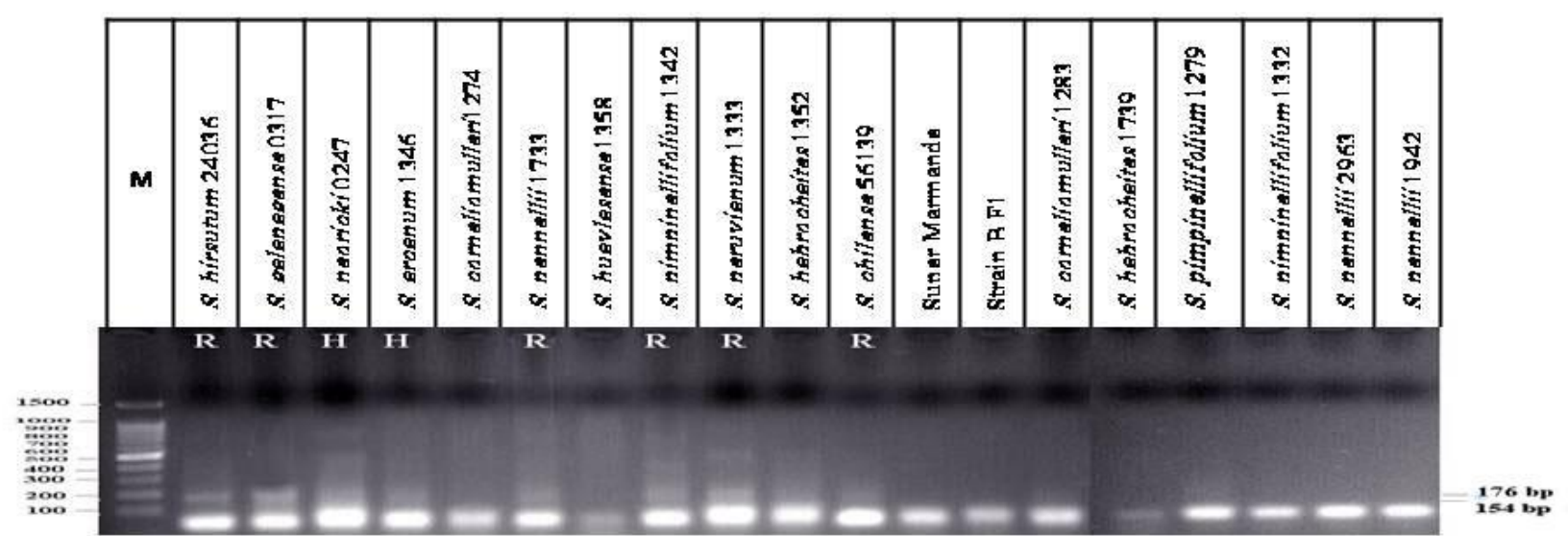

Figure 4. PCR fragments represent primer pair SCAR Ph3 amplified from 19 tomato genotypes, resolved in 1\% agarose gel. Lane M: 100 bp DNA ladder; R= homozygous resistant genotypes; $\mathrm{H}=$ heterozygote resistant genotypes.

\section{Gene-based InDel marker for $C f-9 / C f-4$ resistance}

The primer pair InDel2_Cf-9/Cf-4 was able to amplify a $434 \mathrm{bp}$ PCR product from ten tomato genotypes have only the $C f-9$ resistance allele including $S$. hirsutum 24036, S. galapagense 0317, S. pennellii 1733 and 2963 , S. pimpinellifolium 1342, 1279 and 1332, S. habrochaites 1352, S. chilense 56139 and $S$. lycopersicon cv. Super Marmande (Figure 5 and Table 3 ). On the other hand, the primer set InDel2_Cf-9/Cf-4 gave two bands of 297 and $434 \mathrm{bp}$ in eight wild type tomato species viz., S. neoricki 0247 , S. arcanum 1346 , S. corneliomulleri 1274 and 1283, S. huaylasense 1358, S. peruvianum 1333, S. lycopersicon cv. Strain B F1 and
S. pennellii 1942 carrying both the $C f-4$ and $C f-9$ resistance alleles. In contrast, none of the examined tomato lines has only a $C f-4$ allele. Besides, $S$. habrochaites 1739 has not any $C f-4$ or $C f-9$ resistance loci (Figure 5 and Table 3).

\section{Bacteria-high-efficiency markers for MAS in tomato}

Two gene-based markers related to two bacterial diseases were examined to screen tomato lines carrying resistance alleles. For bacterial spot, pcc12 Indel Rx4 marker was used to the target $R \times 4$. Besides, Pto CAPS markers associated with the Pto gene, responsible for resistance to bacterial speck disease. 


\section{Gene-based InDel marker for $R x 4$ resistance}

Genomic PCR using primer set pcc12 Indel yielded a single band of $119 \mathrm{bp}$ for the recessive allele in all tested tomato genotypes, except $S$. hirsutum 24036 and $S$. galapagense 0317, which have not recorded any products (Figure 6 and Table 3). On the other hand, none of the examined tomato lines has the dominant allele for $R \times 4$ resistance gene.

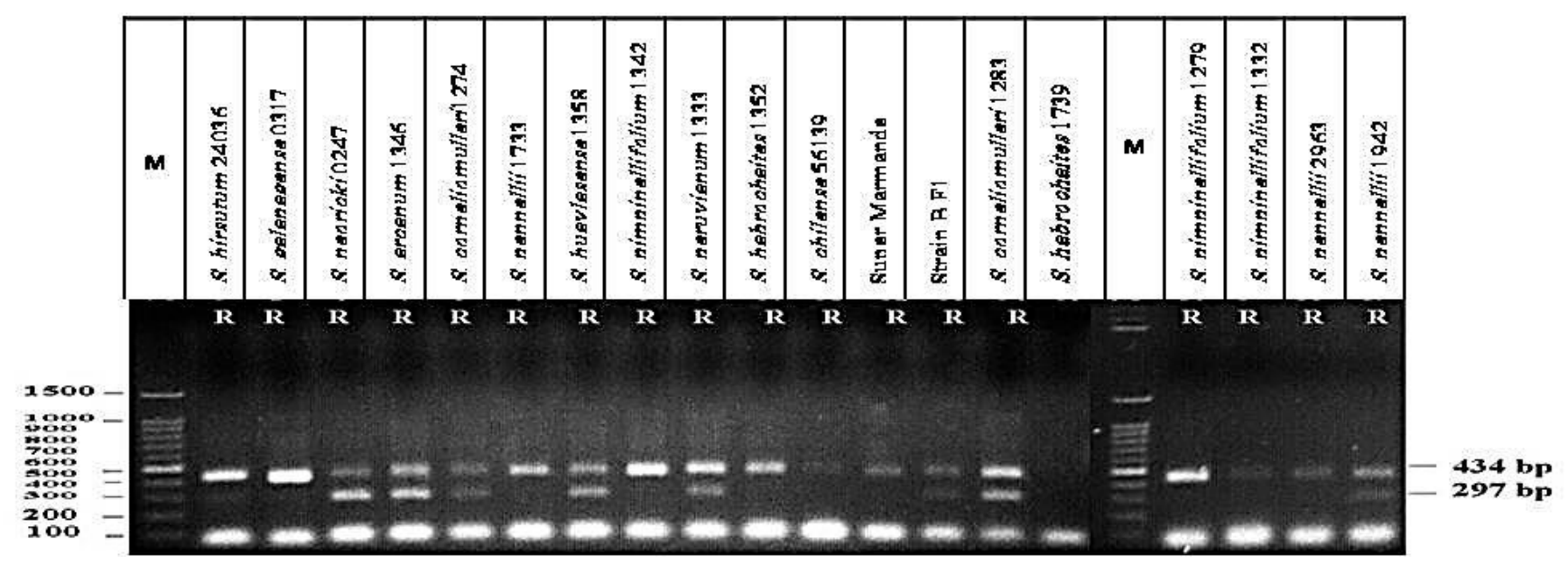

Figure 5. PCR fragments represent primer pair InDel2_Cf-9/Cf-4 amplified from 19 tested tomato genotypes, resolved in 1\% agarose gel. Lane M: 100 bp DNA ladder, $\mathrm{R}=$ homozygous resistant genotypes.

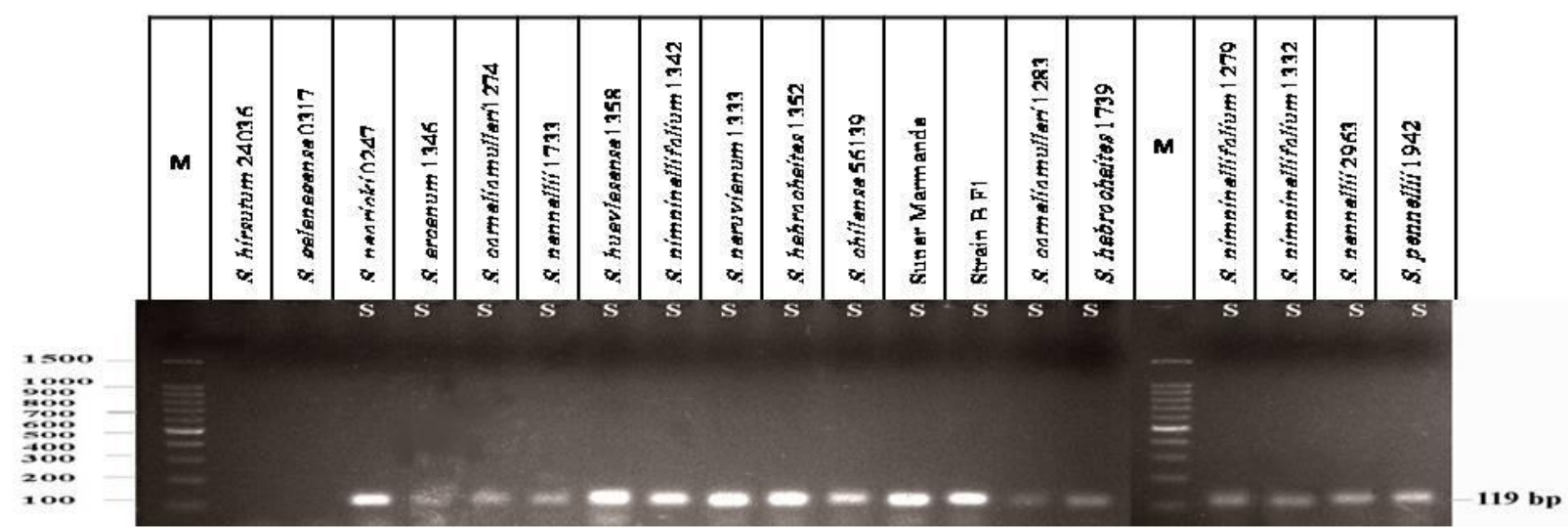

Figure 6. PCR fragments represent primer pair pcc12 Indel Rx4 marker amplified from 19 tested tomato genotypes, resolved in 1\% agarose gel. Lane M: 100 bp DNA ladder; $\mathrm{S}=$ susceptible genotypes.

\section{Gene-based CAPS marker for Pto resistance}

A total number of 19 tomato genotypes were subject to CAPS marker analysis. Primer Pto CAPS amplified a 552 bp band from both bacterial speck resistant and susceptible tomato genotypes (Figure 7a and Table 3). The restriction enzyme RsaI has not cut the amplicon from the homozygous resistant tomato accessions involving S. arcanum 1346, S. corneliomulleri 1274 and 1283, S. pennellii 1733, 2963 and 1942, S. huaylasense 1358, S. pimpinellifolium 1342, 1279 and 1332, S. peruvianum 1333, S. habrochaites 1352 and 1739 and $S$. chilense 56139, but digested the amplicon from the susceptible tomato genotypes into two amplified fragments, 113 and 439 bp (none of the two fragments were obtained in 19 the tested tomato genotypes) (Figure $7 \mathrm{~b}$ and Table 3 ). Besides, pto CAPs primer scored three alleles of $113 \mathrm{bp}, 439$ and $552 \mathrm{bp}$ in the three tomato genotypes, which were heterozygous such as $S$. neoricki 0247, S. lycopersicon cv. Super Marmande and $S$. lycopersicon cv. Strain B F1 (Figure 7b and Table 3). In contrast, S. hirsutum 24036 and S. galapagense 0317 have not shown any bands. None of the tested tomato genotypes carry a recessive allele for the Pto gene (Figure 7 and Table 3). 

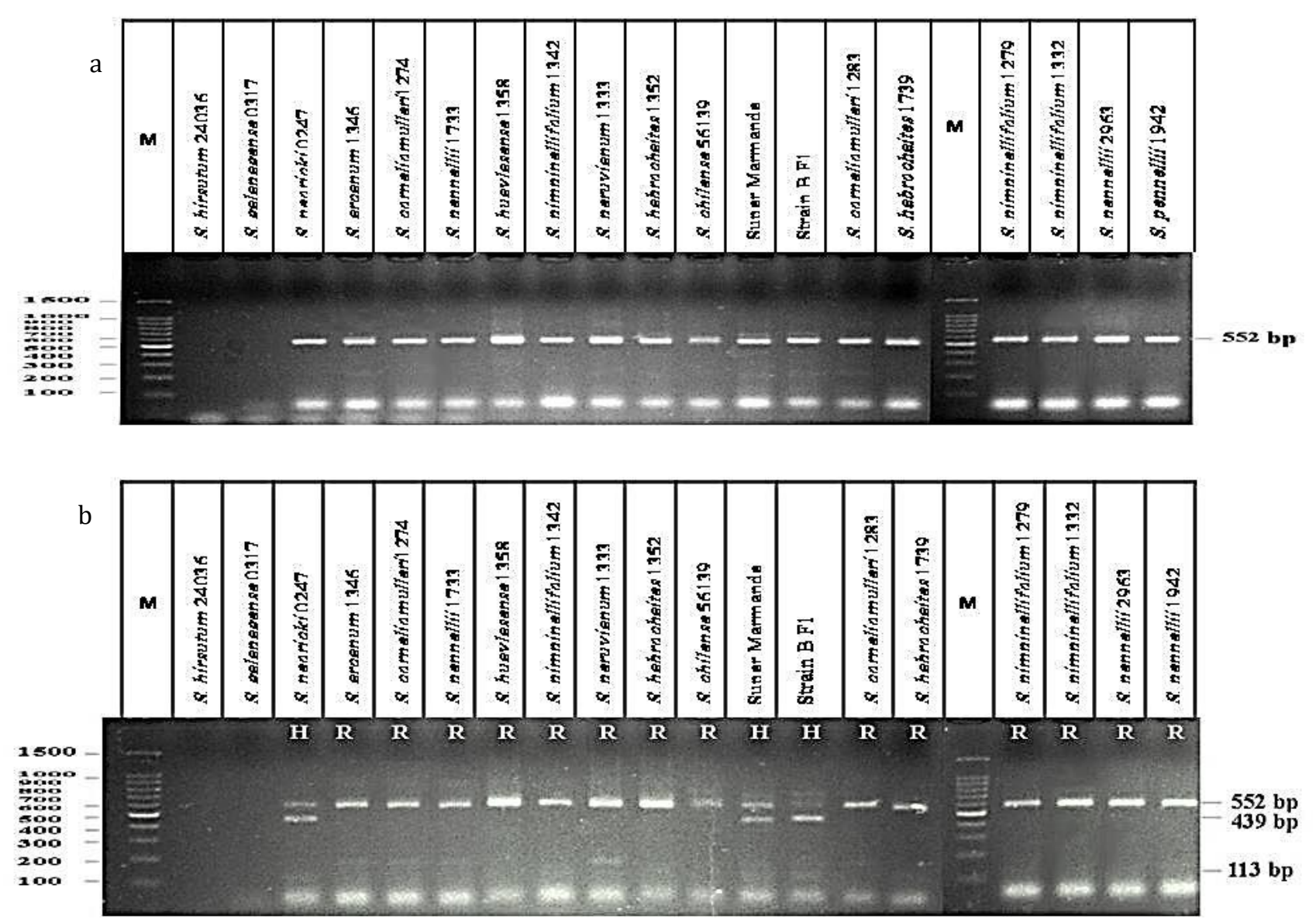

Figure 7. (a) PCR profiles of Pto amplified by CAPS marker from 19 tomato genotypes. (b) Rsal digestion of PCR products amplified by CAPS marker. Lane $\mathrm{M}=100$ bp DNA ladder; $\mathrm{R}=$ homozygous resistant genotypes; $\mathrm{H}=$ heterozygote resistant genotypes.

\section{DISCUSSION}

Production of tomato is being threatened by multiple diseases e.g., fungi, bacteria, viruses, insects, and nematodes. Marker-assisted selection (MAS) is an indirect screening process; whereas a trait of interest is screened depending on molecular markers, which can be applied in the tomato breeding programs for the selection of resistance alleles of pathogens. In this study, we used seven molecular markers linked to three fungal diseases and two bacterial diseases to select tomato lines carrying resistance loci for MAS programs.

In this work, primer set SCAR I1 gave false-positive results for the presence of the $I-1$ locus, responsible for resistance to fusarium wilt disease in the tomato. This marker has not separated resistant and susceptible alleles for the $I-1$ gene. In contrast, primer pair SCAR I1 86.1 well separated both dominant and recessive alleles at each locus. The PCR results successfully amplified DNA amplicons for the $I-1$ locus from both resistant $(314$ bp) and susceptible (583 bp) tomato genotypes. As a result, it is expected that the SCAR I1 86.1 marker would be beneficial for MAS to resistance against fungus $F$. oxysporum f. sp. lycopersici race 1 . These results were in an agreement with Catanzariti and Jones (2010); Takken and Rep (2010) mentioned that fusarium wilt disease threatens tomato production worldwide. Fusarium wilt fungus in tomato is controlled by main genes for resistance introgressed from wild tomato species. The resistance gene $I-1$, introgressed from $S$. pimpinellifolium, refers to resistance against race 1 by recognition of Avr1gene (Houterman et al., 2008). The co-dominant SCAR markers used in this study should permit routine marker-assisted selection (MAS) for resistance to wilt fusarium fungus in the tomato breeding programs. This would allow early screening of resistant lines without inoculation steps, waiting for a long period until the appearance of symptoms. Mutlu et al. (2008) mentioned that co-dominant SCAR markers 
linked to dominant resistance genes against wilt fusarium fungus are more informative and easier in the eggplant breeding programs, compared with other markers.

Our results have not recorded any 19 tested tomato genotypes resistant to verticillium wilt disease. Resistance to $V$. dahlia and $V$. albo-atrum fungi was identified from $S$. lycopersicum line Peru wild and potato plants, respectively (Schaible et al., 1951; Kawchuk et al., 2001). The two resistant loci Ve1 and Ve2 have been identified for resistance to verticillium wilt (Diwan et al., 1999). Arens et al. (2009) developed primers as well as SNP markers to amplify either Ve1 or Ve2. Primers specific to $V e 1$ and $V e 2$ were used to amplify fragments in both susceptible and resistant varieties (homozygous and heterozygous resistance).

In this research, we indicated new tomato genotypes have a dominant allele of $P h 3$ i.e., $S$. hirsutum 24036, $S$. galapagense 0317 , S. pennellii 1733, S. pimpinellifolium 1342, S. peruvianum 1333 and S. chilense 56139. Besides, two resistant wild type tomatoes were heterozygous involving S. neoricki 0247 and S. arcanum 1346. The latter genotypes may be introgressed from lines containing the dominant allele. Resistance sources to late blight disease in tomato are supplied by $P h 3$ gene produced from S. chilense (Miranda et al., 2010; Elsayed et al., 2011), S. hirsutum (Elafifi et al., 2019), S. pennellii (Li et al., 2011), S. pimpinellifolium (Irzhansky and Cohen, 2006; Zhang et al., 2014), S. arcanum (Akhtar et al., 2016) and S. habrochaites LYC4 (Finkers et al., 2007). Our results showed that a co-dominant SCAR marker was effective in differentiation between the homozygous and heterozygous of $P h 3$ allele. This marker gave results matched to results observed by Hittalmani et al. (2000) and Jung et al. (2015) who used the SCAR marker for screening of resistance gene $P h 3$ that can be a powerful tool in tomato breeding programs. Besides, molecular markers can reduce the breeding period. It is clear that the SCAR marker applied in this work would be beneficial for screening tomato lines produced from crossing plants that are resistant to late blight. Consequently using gene-based markers, such as strenuous crossing and offspring testing to genotype the $P h 3$ gene could be averted.

In the current investigation, we discovered that the indel marker discriminated tomato genotypes carrying $C f-9$ from $C f-4$. Genotyping with the Indel marker showed that all tested tomato lines carry the $C f-9$ allele, except $S$. habrochaites 1739. In addition, indel marker amplified products not only from the $C f-9$ gene but also from its homologs. Interestingly, eight tomato accessions carry both the $C f-9$ and the $C f-4$ resistance loci including $S$. neoricki 0247, S. arcanum 1346, S. corneliomulleri 1274 and $1283, S$. huaylasense $1358, S$. peruvianum 1333, S. lycopersicon cv. Strain B F1 and S. pennellii 1942. These lines will be useful in the tomato breeding programs of resistance against leaf mold disease. Similar data were obtained by Kruijt et al. (2005), where they mentioned that the resistance gene $C f-9$ was found in two wild tomato types viz., S. habrochaites and S. pimpinellifolium, while its close homolog, the $C f-4$ resistance allele was indicated in six tomato accessions e.g., $S$. chilense, $S$. peruvianum, $S$. habrochaites, $S$. parviflorum, $S$. lycopersicum and S. chmielewskii. Kim et al. (2017) distinguished between $C f-9$ and $C f-4$ alleles using SNP and InDel markers that will be beneficial for MAS of tomato varieties resistant to leaf mold. Durable resistance to the leaf mold disease caused by fungi $C$. fulvum has been the main purpose for breeders (Rivas and Thomas, 2005). Introgressions of $C f$ genes inside $S$. lycopersicum supplied with genetic resources resistant to leaf mold (Thomas et al., 1997; Kruijt et al., 2005). The $C f-9$ resistance gene was highly homologous with the $C f$ 4 gene with $95.5 \%$ and $91 \%$ at the DNA and amino acid levels, respectively (Parniske et al., 1997; Parniske and Jones, 1999).

In our study, all tested tomato lines recorded susceptible to bacterial spot disease, using pcc12 Indel marker, except Solanum hirsutum 24036 and S. galapagense 0317, which did not show any product. Similar studies were made by Wang et al. (2018) who mentioned that no commercial tomato cultivars are resistant to bacterial diseases. Pei et al. (2011) found that resistance genes to bacterial spot disease from wild tomato species and incorporating them into tomato cultivars are important for disease resistance. The resistant accession $S$. pimpinellifolium PI128216 that carries the $R \times 4$ gene on chromosome 11 referring to hypersensitivity response (HR) and field resistance to Xanthomonas campestris pv. vesicatoria strain T3 (Robbins et al., 2009).

For Pto locus, PCR products of DNA from 19 tomato genotypes and subsequent digestion by RsaI were performed using the CAPS marker. After restriction with RsaI, 14 wild tomato types have resistance gene Pto such as S. corneliomulleri 1274 and 1283, S. peruvianum 1333 and S. chilense 56139 (Hörger, 2011), S. arcanum 1346, 
S. pennellii 1733, 2963 and 1942, S. huaylasense 1358, S. pimpinellifolium 1342, 1279 and 1332 (Orsi et al., 2011), S. habrochaites 1352 and 1739 (Thapa et al., 2015). Furthermore, three tomato lines were heterozygous e.g., S. neoricki 0247, S. lycopersicon cv. Super Marmande and $S$. lycopersicon cv. Strain B F1. These lines were introgressed from tomato germplasms carrying the dominant allele of Pto. These findings were synchronized with results previously obtained by Yang and Francis (2005) who identified the Pto gene responsible for resistance to bacterial speck by a codominant CAPS marker, which is more exhausting and less easy compared with the SCAR marker. Orsi et al. (2011) determined tomato cultivars resistant to Pseudomonas syringae pv. tomato by a semi-dominant allele of $S$. pimpinellifolium that was introgressed into $S$. lycopersicum in the past century. Pedley and Martin (2003) mentioned that the Pto dominant allele was widely applied to bacterial speck resistance in tomato. Because the Pto gene is semi-dominant, symptoms of infection with $P$. syringae pv. tomato were obtained in hybrids, which have one copy of the Pto gene (Pedley and Martin, 2003). Completely resistant lines avert any damage caused by the pathogen, so decreasing agrochemical operations. Besides, seed production companies can benefit from molecular markers linked to the dominant allele (Pto) to generate tomato cultivars resistant to $P$. syringae pv. tomato for breeding programs depending on marker-aided selection (MAS) (Collard and Mackill, 2007).

\section{CONCLUSIONS}

The gene-based markers (SCAR, CAPS, SNP, and InDel) used in this work should permit routine marker-assisted selection (MAS) for resistance against fungal and bacterial pathogens in tomato. In this study, we identified new tomato lines resistant to multiple diseases, and their pyramiding into domesticated tomato will take a short time compared with the classical breeding ways, which require inoculation steps and waiting for a long period till the appearance of symptoms. In addition, the classical breeding ways produce only heterozygous lines, while gene-based markers identify non-segregating homozygous resistant tomato genotypes.

\section{REFERENCES}

Akhtar, K., M. Saleem, Q. Iqbal, M. Asghar, A. Hameed and
N. Sarwar. 2016. Evaluation of tomato genotypes for late blight resistance using low tunnel assay. Journal of Plant Pathology, 98: 421-28.

Arens, P., C. Mansilla, D. Deinum, L. Cavellini, A. Moretti, S. Rolland, H. van der Schoot, D. Calvache, F. Ponz, C. Collonnier, R. Mathis, D. Smilde, C. Caranta and B. Vosman. 2009. Development and evaluation of robust molecular markers linked to disease resistance in tomato for distinctness, uniformity and stability testing. Theoretical and Applied Genetics, 120: 655-64.

Astua-Monge, G., G. V. Minsavage, R. E. Stall, C. E. Vallejos, M. J. Davis and J. B. Jones. 2000. Xv4-vrxv4: A new gene-for-gene interaction identified between Xanthomonas campestris pv. Vesicatoria Race T3 and the wild tomato relative Lycopersicon pennellii. Molecular Plant-Microbe Interactions, 13: 1346-55.

Bohn, G. W. and C. M. Tucker. 1939. Immunity to Fusarium wilt in the tomato. Science, 89: 603-04.

Catanzariti, A.-M. and D. A. Jones. 2010. Effector proteins of extracellular fungal plant pathogens that trigger host resistance. Functional Plant Biology, 37: 901.

Collard, B. C. Y. and D. J. Mackill. 2007. Marker-assisted selection: An approach for precision plant breeding in the twenty-first century. Philosophical Transactions of the Royal Society B: Biological Sciences, 363: 557-72.

Diwan, N., R. Fluhr, Y. Eshed, D. Zamir and S. D. Tanksley. 1999. Mapping of Ve in tomato: A gene conferring resistance to the broad-spectrum pathogen, Verticillium dahliae race 1 . Theoretical and Applied Genetics, 98: 315-19.

Dixon, M. S., D. A. Jones, J. S. Keddie, C. M. Thomas, K. Harrison and J. D. G. Jones. 1996. The tomato $C f-2$ disease resistance locus comprises two functional genes encoding leucine-rich repeat proteins. Cell, 84: 451-59.

Dixon, M. S., K. Hatzixanthis, D. A. Jones, K. Harrison and J. D. G. Jones. 1998. The tomato Cf-5 disease resistance gene and six homologs show pronounced allelic variation in leucine-rich repeat copy number. The Plant Cell, 10: 1915-25.

Elafifi, S. T., W. A. Ramadan, W. A. El-Saady and P. A. Abdelmalek. 2019. Inheritance of resistance against Phytophthora infestans in wild tomato genotype (Lycopersicon hirsutum 103684). Journal of Plant Production, 10: 675-79. 
Elsayed, A., D. da Silva Henriques, E. Mizubuti and C. Carneiro. 2011. Combing the monogenic and polygenic resistant genes to late blight in tomato. Journal of Plant Breeding and Crop Science, 3: 251-59.

Finkers, R., A. W. van Heusden, F. Meijer-Dekens, J. A. L. van Kan, P. Maris and P. Lindhout. 2007. The construction of a Solanum habrochaites LYC4 introgression line population and the identification of QTLs for resistance to Botrytis cinerea. Theoretical and Applied Genetics, 114: 1071-80.

Foolad, M. R. 2007. Genome mapping and molecular breeding of tomato. International Journal of Plant Genomics, 21: 1-52.

Foolad, M. R., H. L. Merk and H. Ashrafi. 2008. Genetics, genomics and breeding of late blight and early blight resistance in tomato. Critical Reviews in Plant Sciences, 27: 75-107.

Fradin, E. F. and B. P. H. J. Thomma. 2006. Physiology and molecular aspects of verticillium wilt diseases caused by $V$. dahliae and $V$. albo-atrum. Molecular Plant Pathology, 7: 71-86.

Gonzalez-Cendales, Y., A.-M. Catanzariti, B. Baker, D. J. McGrath and D. A. Jones. 2015. Identification of $I-7$ expands the repertoire of genes for resistance to fusarium wilt in tomato to three resistance gene classes. Molecular Plant Pathology, 17: 448-63.

Grattidge, R. 1982. Occurrence of a third race of fusarium wilt of tomatoes in Queensland. Plant Disease, 66: 165-78.

Hittalmani, S., A. Parco, T. V. Mew, R. S. Zeigler and N. Huang. 2000. Fine mapping and DNA markerassisted pyramiding of the three major genes for blast resistance in rice. Theoretical and Applied Genetics, 100: 1121-28.

Hörger, A. C. 2011. Evolution of disease resistance genes in wild tomato species, LMU München, Faculty of Biology.

Houterman, P. M., B. J. C. Cornelissen and M. Rep. 2008. Suppression of plant resistance gene-based immunity by a fungal effector. PLoS Pathogens, 4 : e1000061.

Irzhansky, I. and Y. Cohen. 2006. Inheritance of resistance against Phytophthora infestans in Lycopersicon pimpenellifolium L3707. Euphytica, 149: 309-16.

Jia, Y., Y. T. Loh, J. Zhou and G. B. Martin. 1997. Alleles of
Pto and Fen occur in bacterial speck-susceptible and fenthion-insensitive tomato cultivars and encode active protein kinases. The Plant Cell, 9: 61-73.

Jones, J. B., R. E. Stall and H. Bouzar. 1998. Diversity among xanthomonads pathogenic on pepper and tomato. Annual Review of Phytopathology, 36: 4158.

Jung, J., H. J. Kim, J. M. Lee, C. S. Oh, H.-J. Lee and I. Yeam. 2015. Gene-based molecular marker system for multiple disease resistances in tomato against Tomato yellow leaf curl virus, late blight, and verticillium wilt. Euphytica, 205: 599-613.

Kawchuk, L. M., J. Hachey, D. R. Lynch, F. Kulcsar, G. van Rooijen, D. R. Waterer, A. Robertson, E. Kokko, R. Byers, R. J. Howard, R. Fischer and D. Prufer. 2001. Tomato Ve disease resistance genes encode cell surface-like receptors. Proceedings of the National Academy of Sciences, 98: 6511-15.

Kim, B., I. S. Hwang, H.-J. Lee and C.-S. Oh. 2017. Combination of newly developed SNP and InDel markers for genotyping the $C f-9$ locus conferring disease resistance to leaf mold disease in the tomato. Molecular Breeding, 37: 59-68.

Kim, M.-J. and M. A. Mutschler. 2006. Characterization of late blight resistance derived from Solanum pimpinellifolium L3708 against multiple isolates of the pathogen Phytophthora infestans. Journal of the American Society for Horticultural Science, 131: 637-45.

Kole, C., H. Ashrafi, G. Lin and M. Foolad. 2006. Identification and molecular mapping of a new $R$ gene, $P h-4$, conferring resistance to late blight in tomato. Solanaceae Conference, University of Wisconsin, Madison.

Kruijt, M., D. J. Kip, M. H. A. J. Joosten, B. F. Brandwagt and P. J. G. M. de Wit. 2005. The $C f-4$ and $C f-9$ resistance genes against Cladosporium fulvum are conserved in wild tomato species. Molecular Plant-Microbe Interaction, 18: 1011-21.

Lee, J. M., C.-S. Oh and I. Yeam. 2015. Molecular markers for selecting diverse disease resistances in tomato breeding programs. Plant Breeding and Biotechnology, 3: 308-22.

Li, J., L. Liu, Y. Bai, R. Finkers, F. Wang, Y. Du, Y. Yang, B. Xie, R. G. F. Visser and A. W. van Heusden. 2011. Identification and mapping of quantitative resistance to late blight (Phytophthora infestans) 
in Solanum habrochaites LA1777. Euphytica, 179: 427-38.

Mahfouze, S. A. and H. A. Mahfouze. 2019. A comparison between CAPS and SCAR markers in the detection of resistance genes in some tomato genotypes against Tomato yellow leaf curl virus and whitefly. Jordan Journal of Biological Sciences, 12: 123-33.

Merk, H. L., H. Ashrafi and M. R. Foolad. 2012. Selective genotyping to identify late blight resistance genes in an accession of the tomato wild species Solanum pimpinellifolium. Euphytica, 187: 63-75.

Merk, H. L. and M. R. Foolad. 2011. Parent-offspring correlation estimate of heritability for late blight resistance conferred by an accession of the tomato wild species Solanum pimpinellifolium. Plant Breeding, 131: 203-10.

Miranda, B. E. C. d., N. D. Suassuna and A. Reis. 2010. Mating type, mefenoxam sensitivity, and pathotype diversity in Phytophthora infestans isolates from tomato in Brazil. Pesquisa Agropecuária Brasileira, 45: 671-79.

Mutlu, N., F. H. Boyacı, M. Göçmen and K. Abak. 2008. Development of SRAP, SRAP-RGA, RAPD and SCAR markers linked with a fusarium wilt resistance gene in eggplant. Theoretical and Applied Genetics, 117: 1303-12.

Orsi, I., M. Malatrasi, E. Belfanti, M. Gullì and N. Marmiroli. 2011. Determining resistance to Pseudomonas syringae in tomato, a comparison of different molecular markers. Molecular Breeding, 30: 967-74.

Parniske, M., K. E. Hammond-Kosack, C. Golstein, C. M. Thomas, D. A. Jones, K. Harrison, B. B. H. Wulff and J. D. G. Jones. 1997. Novel disease resistance specificities result from sequence exchange between tandemly repeated genes at the $C f-4 / 9$ locus of tomato. Cell, 91: 821-32.

Parniske, M. and J. D. G. Jones. 1999. Recombination between diverged clusters of the tomato $C f-9$ plant disease resistance gene family. Proceedings of the National Academy of Sciences, 96: 5850-55.

Pedley, K. F. and G. B. Martin. 2003. Molecular basis of pto-mediated resistance to bacterial speck disease in tomato. Annual Review of Phytopathology, 41: 215-43.

Pei, C., H. Wang, J. Zhang, Y. Wang, D. M. Francis and W. Yang. 2011. Fine mapping and analysis of a candidate gene in tomato accession PI128216 conferring hypersensitive resistance to bacterial spot race T3. Theoretical and Applied Genetics, 124: 533-42.

Peries, 0. 1971. Environmental factors affecting plant diseases. Tea Q 42, 42: 188-95.

Rivas, S. and C. M. Thomas. 2005. Molecular interactions between tomato and the leaf mold pathogen Cladosporium fulvum. Annual Review of Phytopathology, 43: 395-436.

Robbins, M. D., A. Darrigues, S.-C. Sim, M. A. T. Masud and D. M. Francis. 2009. Characterization of hypersensitive resistance to bacterial spot race $\mathrm{T} 3$ (Xanthomonas perforans) from tomato accession PI 128216. Phytopathology, 99: 1037-44.

Rodewald, J. and B. Trognitz. 2013. Solanum resistance genes against Phytophthora infestans and their corresponding avirulence genes. Molecular Plant Pathology, 14: 740-57.

Salmeron, J. M., G. E. D. Oldroyd, C. M. T. Rommens, S. R. Scofield, H.-S. Kim, D. T. Lavelle, D. Dahlbeck and B. J. Staskawicz. 1996. Tomato Prf is a member of the leucine-rich repeat class of plant disease resistance genes and lies embedded within the Pto kinase gene cluster. Cell, 86: 123-33.

Schaible, L., O. S. Cannon and V. Waddoups. 1951. Inheritance of resistance to verticillium wilt in a tomato cross. Phytopathology, 41: 986-90.

Scott, J. and J. Jones. 1989a. Inheritance of resistance to foliar bacterial spot of tomato incited by Xanthomonas campestris pv. vesicatoria. Journal of the American Society for Horticultural Science, 114: 111-14.

Scott, J. and J. Jones. 1989b. Monogenic resistance in tomato to Fusarium oxysporum f. sp. lycopersici race 3. Euphytica, 40: 49-53.

Shi, A. and R. Vierling. 2011. Identification of molecular markers for $\mathrm{Sw}-5$ gene of Tomato spotted wilt virus resistance. American Journal of Biotechnology and Molecular Sciences, 1: 8-16.

Simons, G., J. Groenendijk, J. Wijbrandi, M. Reijans, J. Groenen, P. Diergaarde, T. V. der Lee, M. Bleeker, J. Onstenk, M. de Both, M. Haring, J. Mes, B. Cornelissen, M. Zabeau and P. Vos. 1998. Dissection of the Fusarium I2 gene cluster in tomato reveals six homologs and one active gene copy. The Plant Cell, 10: 1055-67.

Takken, F. and M. Rep. 2010. The arms race between tomato and Fusarium oxysporum. Molecular Plant 
Pathology, 11: 309-14.

Takken, F. L. W., C. M. Thomas, M. H. A. J. Joosten, C. Golstein, N. Westerink, J. Hille, H. J. J. Nijkamp, P. J. G. M. De Wit and J. D. G. Jones. 1999. A second gene at the tomato $C f-4$ locus confers resistance to Cladosporium fulvum through recognition of a novel avirulence determinant. The Plant Journal, 20: 279-88.

Thapa, S. P., E. M. Miyao, R. Michael Davis and G. Coaker. 2015. Identification of QTLs controlling resistance to Pseudomonas syringae pv. tomato race 1 strains from the wild tomato, Solanum habrochaites LA1777. Theoretical and Applied Genetics, 128: 681-92.

Thomas, C. M., D. A. Jones, M. Parniske, K. Harrison, P. J. Balint-Kurti, K. Hatzixanthis and J. D. Jones. 1997. Characterization of the tomato $C f-4$ gene for resistance to Cladosporium fulvum identifies sequences that determine recognitional specificity in $C f-4$ and $C f-9$. The Plant Cell, 9: 2209-24.

van Ooijen, G., H. A. van den Burg, B. J. C. Cornelissen and F. L. W. Takken. 2007. Structure and function of resistance proteins in solanaceous plants. Annual Review of Phytopathology, 45: 43-72.

Wang, H., S. F. Hutton, M. D. Robbins, S.-C. Sim, J. W. Scott,
W. Yang, J. B. Jones and D. M. Francis. 2011. Molecular mapping of hypersensitive resistance from tomato 'Hawaii 7981' to Xanthomonas perforans Race T3. Phytopathology, 101: 1217-23.

Wang, Y., Y. Zhang, Z. Gao and W. Yang. 2018. Breeding for resistance to tomato bacterial diseases in China: Challenges and prospects. Horticultural Plant Journal, 4: 193-207.

Yang, W. and D. M. Francis. 2005. Marker-assisted selection for combining resistance to bacterial spot and bacterial speck in tomato. Journal of the American Society for Horticultural Science, 130: 716-21.

Zhang, C., L. Liu, X. Wang, J. Vossen, G. Li, T. Li, Z. Zheng, J. Gao, Y. Guo, R. G. F. Visser, J. Li, Y. Bai and Y. Du. 2014. The Ph-3 gene from Solanum pimpinellifolium encodes CC-NBS-LRR protein conferring resistance to Phytophthora infestans. Theoretical and Applied Genetics, 127: 1353-64.

Zhang, C., L. Liu, Z. Zheng, Y. Sun, L. Zhou, Y. Yang, F. Cheng, Z. Zhang, X. Wang, S. Huang, B. Xie, Y. Du, Y. Bai and J. Li. 2013. Fine mapping of the $P h-3$ gene conferring resistance to late blight (Phytophthora infestans) in tomato. Theoretical and Applied Genetics, 126: 2643-53.

\section{Conflict of Interest}

The authors declare that they have no competing interests.

\section{Author's Contribution}

HAM carried out the practical experiments and analysis of data and SAM collected the data and wrote the paper.

Publisher's note: EScience Press remains neutral with regard to jurisdictional claims in published maps and institutional affiliations.

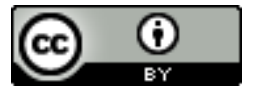

Open Access This article is licensed under a Creative Commons Attribution 4.0 International License, which permits use, sharing, adaptation, distribution and reproduction in any medium or format, as long as you give appropriate credit to the original author(s) and the source, provide a link to the Creative Commons license and indicate if changes were made. The images or other third-party material in this article are included in the article's Creative Commons license, unless indicated otherwise in a credit line to the material. If material is not included in the article's Creative Commons license and your intended use is not permitted by statutory regulation or exceeds the permitted use, you will need to obtain permission directly from the copyright holder. To view a copy of this license, visit http://creativecommons.org/licenses/by/4.0/. 